\title{
SYNTHESIS OF WAX IN THE HONEYBEE (APIS MELLIFERA L.)
}

\author{
T. PIEK* \\ Laboratory of Chemical Animal Physiology, University of Utrecht, The Netherlands
}

(Received 26 Fanuary 1964)

\begin{abstract}
Newly emerged honeybee workers were fed during 1 or 2 weeks with sucrose containing either heavy water, sodium acetate with deuterium, sodium acetate $-1{ }^{14} \mathrm{C}$, or uniformly labelled glucose $-{ }^{14} \mathrm{C}$. The various lipid fractions were isolated in order to investigate the origin of the secreted wax componen.ts. In feeding acetate with deuterium or ${ }^{14} \mathrm{C}$ the isolated hydrocarbons and free wax acids were strongly labelled, but not the esters or their component acids and alcohols. Feeding uniformly labelled glucose or heavy water caused no extreme differences in the labelling of different lipid fractions. Radioactivity of the oenocytes was 30 per cent higher than that of the fat cells (micro-autoradiographic asisays) after feeding acetate- $1-{ }^{14} \mathrm{C}$, but no distinct difference was found after feeding uniformly labelled glucose ${ }^{14} \mathrm{C}$. In order to interpret these facts we supposed that the oenocytes take up directly the acctate fed to the animals, whereas the fat cells do not. The hypothesis is put forward that oenocytes synthesize wax acids and hydrocarbons from acetate originating from the glycolysis in the fat cells, and that fat cells synthesize the esters as wcll as their component acids and alcohols from acetate originating from the glycolysis in these cells.
\end{abstract}

\section{INTRODUCTION}

THE secretion of wax by the honeybee workers was first described by JoHN in 1684, who observect that the wax permeates through the folds at both sides of the abdomen, contrary to earlier investigators, who supposed that wax was collected by the bees from the plants they visit in the field. In 1814 Huber concluded from his experiments that the production of wax is a faculty of the bees themselves. A review of the work of other authors was given by DREYLING (1905), who concluded from anatomical investigations that wax permeates via pores in the cuticle. This conclusion was rejected in 1952 by ReIMANN, who found no evidence for such pores in his electromicrographs. Ilowever, wax-secreting pores were found in larvae of Calapodes ethlius (Lepidoptera) by LOCKE (1960).

How beeswax flows out through the abdominal cuticle is still unknown. The conception of HoldGate and SEAL (1956) that the secondary wax layer of Tenebrio-pupae develops by crystallization of the excess of wax in the cement does not hold good in the case of Apis adults, since GlynNe-Jones (1955) stated that

* Present address: The Pharmacological Laboratory of the University of Amsterdam, Polderweg 20, Amsterdam, The Netherlands. 
a cement layer is not formed on the primary wax layer. BEAMENT (1955) described a liquid fat formed by Periplaneta, which consists of two fractions with a mol. wt. of respectively $120-170$ and $300-350$. He thinks that wax flows through the cuticle as a liquid.

The cuticulin layer of Rhodnius (WIgGlesworth, 1947) and Tenebrio (Wigglesworth, 1948a) consists of lipoproteins (Wigglesworth, 1948c). According to Dennel and MaLik (1956), in Periplaneta and Calliphora this layer consists of proteins and sterols in the form of lipoproteins.

Since the formation of the cuticulin layer runs parallel to the secretory cycle of the subepidermal oenocytes, WIGGLeswORTH (1948b) supposed that this layer is formed by the ocnocytes. The fat cells and oenocytes play a prominent part in the biosynthesis of beeswax (Hollande, 1914; Rösch, 1930; REImanN, 1952). Hollande assumed that both fat cells and oenocytes transmit their products to the wax glands. REImanN (1952) discovered the relation between the oenocytes and fat cells. From this work we cite:

Gleichzeitig mit der Entwicklung der Wachsdrüse beginnt die Entfaltung des Fettkörpers. Hierbei verschwindet der grossvakuolige Charakter des Plasmas in den Fettzellen, wie er von schlüpfenden Bienen bekannt ist. Der Kern vergrössert seinen Umfang und verliert dadurch seine abgeplattete Form. Während für die Fettzellen, deren Grösse schon bei schlüpfenden Bienen sehr verschieden ist, eine Zunahme des Volumens nicht sicher nachgewiesen werden konnte, ist sie bei den Oenocyten sehr deutlich.

Fettzellen und Oenocyten treten in engste Beziehungen. Eine Gesetzmässigkeit lässt sich hierbei nicht feststellen. Die Fettzellen können nur an einer Stelle etwas eingedellt werden; ein andermal liegt die Oenocyte tief in die Fettzelle. Liegt eine Fettzelle zwischen zwei Oenocyten, die sich gleichzeitig vergrössert haben, so wird sie von beiden Seiten zusammen gepresst; das kann soweit gehen, dass zwischen die Oenocyten zuletzt nur mehr ein schmaler Plasmastreifen als Rest der Fettzelle erhalten bleibt.

Aus dem histologischen Bild ist zu schliessen, das zwischen Fettzellen und Oenocyten ein Stoffaustausch stattfindet. Ich hatte den Eindruck, dass dabei sogar die Plasmasubstanz der Fettzellen verbraucht wird. Nicht selten hängt nur mehr ein kleiner Rest einer Fettzelle wie eine Kappe halbmondförmig an der Oenocyte. Die Zellmembran wird an der Grenze von Oenocyte und Fettzelle (die Zellwände werden sonst deutlich gefärbt) an einzelnen Berührungsstellen aufgelöst. Ein Übertreten von Fettstoffen, die sich bei Osmierung schwarz färben, aus der Fettzelle in die Oenocyte konnte nie bemerkt werden.

According to WARTH (1947) beeswax consists of hydrocarbons (about 12 per cent), esters (about 72 per cent) and free wax acids (about 13 per cent). In earlier publications (PIEK, 1961, 1962) we stated that when newly emerged honeybee workers were fed with sucrose containing either deuterium-labelled sodium acetate or sodium acetate- $1{ }^{14} \mathrm{C}$, the isolated hydrocarbons and free wax acids were strongly labelled, whereas the esters or their component acids and alcohols were weakly labelled. This applies equally to the compounds isolated from the bees as well as to those isolated from the secreted wax. In order to study these effects more closely we have continued the experiments by feeding young bees with labelled glucose and labelled acetate. In this way we hoped to demonstrate differences in the radioactivity hetween the nenocytes and the fat cells. 


\section{MATERIAL AND METHODS}

In order to investigate the biosynthesis of wax components, experiments were carried out in the months of May, June, and July with newly emerged workers of which about 750 were kept in five Liebefelder cages in the presence of dead queens (DE Groot, 1953a, b) in order to induce the building of combs. These bees were fed during 10-20 days with a sucrose paste containing tracers. Thereafter the animals were killed with chloroform, dried (after excision of the gut), and extracted with petroleum ether (b.p. $40-60^{\circ} \mathrm{C}$ ). This extract and the combs dissolved in petroleum ether were fractionated into hydrocarbons, fatty acids, wax acids, and alcohols. In the experiments with deuterium the fatty acids and the wax acids were obtained in one fraction.

For obtaining these various fractions a combination of techniques was applied as described by Spengler and Wöllner (1954), Fuchs and DE JoNg (1954) and SEIDEL et al. (1944). The wax obtained by extraction was dissolved in a minimal quantity of carbon tetrachloride and separated into fractions by means of chromatography on columns of alumina (Brockmann). Fraction 1 was obtained by successive elution with carbon tetrachloride and toluene, fraction 2 by using chloroform with $5 \%$ acetic acid, and fraction 3 by means of ether.

After evaporation, fraction 1 was taken up in the smallest possible quantity of petroleum ether (b.p. $40-60^{\circ} \mathrm{C}$ ) and separated on a column of silica gel (previously heated to red heat) by means of petroleum ether (fraction 1 a) and ether (fraction $1 \mathrm{~b}$ ). After determination of the respective ester, saponification, and acid values it appeared that fraction 1 a consisted of hydrocarbons, $1 \mathrm{~b}$ of ester 1 (ester value 70-76; probably myricylcerotate), fraction 2 of ester 2 (ester value 86-88; esters with acids C-16), and fraction 3 of free wax acids.

These various fractions were evaporated to dryness, combusted in a Pregl oven, and from the resulting water the atom-per cent-excess of deuterium was determined by means of the falling drop method (Keston et al., 1937).

The fractions obtained from the animals fed with ${ }^{14} \mathrm{C}$-labelled acetate and glucose were combusted and the $\mathrm{CO}_{2}$ converted into barium carbonate. From an 'infinitely thick layer' of this carbonate the activity was determined by means of a thin-end window counter (Philips tube 18505 and Philips scaler PW 4035). According to Calvin et al. (1949) the values obtained in this way (expressed as counts/min) are proportional to the specific activity and thus suitable for comparison.

In two series, first after feeding actate- $1{ }^{14} \mathrm{C}$, and second after feeding uniformly labelled glucose- ${ }^{14} \mathrm{C}$, we observed the radioactivity of both oenocytes and fat cells by means of rnicro-autoradiography.

The fat bodies, present above the wax glands as a monocellular layer, were isolated and fixed to the object glass by means of chromiumalum gelatin (GATENBY and CowDry, 1937-ref. in GRAY, 1954). After drying in air the slides were covered with a Kodak AR 10 stripping film; afterwards they were irradiated during 4 weeks at $5^{\circ} \mathrm{C}$. After processing, the slides were stained with haematoxylin after Ehrlich at $5^{\circ} \mathrm{C}$ for $2 \mathrm{hr}$ (Benge, 1960). 
The microphotographs were made by phase contrast in monochromatic green light (magnification $400 \times$ ).

\section{EXPERIMENTS}

(1) Experiments with heavy water

Bees were fed during 2 weeks with sugar paste containing 2 per cent heavy water. After that period their body fluid contained 0.27 atom-per cent-excess deuterium. After excision of the gut the weight of the bees was $93 \mathrm{~g}$ from which amount $7 \mathrm{~g}$ wax could be extracted by means of petroleum ether. The comb had a weight of $4 \mathrm{~g}$. The results of the experiments are shown in Table 1.

TABle 1-ATOM-PER CENT-EXCESS DEUTERIUM AFTER INGESTION OF HEAVY WATER

$\begin{array}{lll}\text { Water of the food } & 2 \cdot 000 \\ \text { Water of the gut (distilled) } & 0 \cdot 39 \pm 0 \cdot 01 & n^{*}=10 \\ \text { Body water (distilled) } & 0 \cdot 27 \pm 0 \cdot 01 & n=10 \\ \text { Petroleum ether extract of eviscerated bees } & 0 \cdot 19 \pm 0 \cdot 01 & n=10 \\ \quad \text { Hydrocarbons } & 0 \cdot 13 \pm 0 \cdot 02 & n=6 \\ \quad \text { Alcohols } & 0 \cdot 09 \pm 0 \cdot 04 & n=4 \\ \quad 0 \cdot 15 \pm 0 \cdot 02 & n=6 \\ \text { Total acids } & 0 \cdot 24 \pm 0 \cdot 01 & n=10 \\ \text { Petroleum ether extract of combs } & 0 \cdot 15 \pm 0 \cdot 03 & n=4 \\ \quad \text { Hydrocarbons } & 0 \cdot 15 \pm 0 \cdot 06 & n=4 \\ \text { Total acids } & & \end{array}$

$* n=$ number of analyses.

\section{(2) Experiments with deuterio-acetate}

Bees were fed during 10-20 days with sucrose containing 1 per cent of deuterium-labelled sodium acetate (atom-per cent-excess 42). The weight (without gut) was $210 \mathrm{~g}$ (dry weight $65 \mathrm{~g}$ ), $5 \mathrm{~g}$ wax could be extracted by means of petroleum ether. The comb had a weight of $0.7 \mathrm{~g}$. The atom-per cent-excess of the lipid fractions is given in Table 2.

Table 2-Atom-Per Cent-excess deuterium after ingestion of DEUTERIUM-LABELLLED SODIUM ACETATE

\begin{tabular}{lll}
\hline Food & $0 \cdot 20 \pm 0.02$ & $n^{*}=3$ \\
Body water & $0 \cdot 06 \pm 0.01$ & $n=10$ \\
Water of the gut & $0 \cdot 06 \pm 0.01$ & $n=10$ \\
Extract of eviscerated bees & $0 \cdot 03 \pm 0.01$ & $n=10$ \\
$\quad$ Hydrocarbons & $0 \cdot 32 \pm 0.08$ & $n=3$ \\
$\quad$ Alcohols & $0 \cdot 01 \pm 0.01$ & $n=6$ \\
$\quad$ Total acids & $0 \cdot 17 \pm 0.02$ & $n=3$ \\
Extract of the comb & $0 \cdot 06 \pm 0.01$ & $n=6$ \\
\hline
\end{tabular}

$* n=$ number of analyses. 
(3) Experiments with acetate $-1-{ }^{14} C$

About 1000 bees were fed with $550 \mathrm{~g}$ sugar paste, mixed with $0.223 \mathrm{~g}$ sodium acetate- $1-{ }^{14} \mathrm{C}$ (activity of the acetate after combustion and conversion into barium carbonate was 22 counts $/ \mathrm{min}$; sp. act. $5 \cdot 7 \times 10^{-10} \mathrm{mC}$ ). From $35 \mathrm{~g}$ dry material we extracted $3 \mathrm{~g}$ lipids. The petroleum ether extract of the comb weighed $5 \mathrm{~g}$.

From Table 1 we may conclude that, whenever heavy water is given, the tracer is incorporated more or less equally in the various lipid fractions of the eviscerated bees (highest value is found in the extract of the combs). This could be expected, as water will take part in nearly all the equilibrium reactions involved in the synthesis of different compounds in the animal.

\begin{tabular}{|c|c|}
\hline & Counts/min \\
\hline Food & $22 \cdot 0$ \\
\hline Food stored in comb & $17 \cdot 1$ \\
\hline $\mathrm{CO}_{2}$ excreted (after $\left.4 \mathrm{hr}\right)$ & $27-5$ \\
\hline $\mathrm{CO}_{2}$ excreted (after 2 days) & $55 \cdot 8$ \\
\hline $\mathrm{CO}_{2}$ excreted (after 4,5 days) & $29 \cdot 1$ \\
\hline $\mathrm{CO}_{2}$ excreted (after 7 days) & $22 \cdot 1$ \\
\hline $\mathrm{CO}_{2}$ excreted (after 11 days) & $38 \cdot 7$ \\
\hline Petroleum ether extract of crop (honey stomach) & $132 \cdot 2$ \\
\hline Petroleum ether extract of ventriculus & 623.7 \\
\hline Petroleum ether extract of end gut & $155 \cdot 1$ \\
\hline Petroleum ether extract of eviscerated bees & $124 \cdot 7$ \\
\hline Fraction hydrocarbons & $126 \cdot 5$ \\
\hline \multicolumn{2}{|l|}{ Fraction ester 1 (ester value 76$)^{*}$} \\
\hline Alcohols & $18 \cdot 7$ \\
\hline Acids & $21 \cdot 5$ \\
\hline \multicolumn{2}{|l|}{ Fraction ester 2 (ester value 88 )* } \\
\hline Alcohols & $39 \cdot 9$ \\
\hline Acids & $84 \cdot 6$ \\
\hline Fraction free wax acids & $129 \cdot 4$ \\
\hline Petroleum ether extract of comb & $32 \cdot 6$ \\
\hline Fraction hydrocarbons & $137 \cdot 6$ \\
\hline \multicolumn{2}{|l|}{ Fraction ester 1 (ester value 70$)^{*}$} \\
\hline Alcohols & $13 \cdot 7$ \\
\hline Acids & $15 \cdot 6$ \\
\hline \multicolumn{2}{|l|}{ Fraction ester 2 (ester value 86$)^{*}$} \\
\hline Alcohols & $9 \cdot 9$ \\
\hline Acids & $22 \cdot 5$ \\
\hline Fraction free wax acids & $131 \cdot 0$ \\
\hline Chitin & $15 \cdot 1$ \\
\hline Rest (chiefly amino acids) & $17 \cdot 6$ \\
\hline
\end{tabular}

* Fraction ester 1 consists of esters with acids C-24; myricylcerotate. Fraction ester 2 of esters with C-16 acids. 
However, from Tables 2 and 3 we may infer that in feeding acetate, great differences arise in the extent to which the different isolated substances are labelled. In the extracts of the animals as well as in those of the combs, by far the strongest labelling is found in the hydrocarbons and in the free wax acids. The esters, their fatty acids, and their alcohols were labelled much more weakly whether we fed deuterio-acetate or ${ }^{14} \mathrm{C}$-labelled acetate. These results, combined with the histological data mentioned in the Introduction, point to synthesis of the various compounds in different kinds of tissues.

The numbers in Table 3 not concerned with lipid substances may give an impression of the distribution of the tracer in other compounds or tissues.

(4) Experiments with glucose- ${ }^{14} \mathrm{C}$

In these experiments the bees were fed during 10 days with $400 \mathrm{~g}$ sugar paste containing $250 \mu \mathrm{c}$ uniformly labelled glucose- ${ }^{14} \mathrm{C}$. The bees built $1720 \mathrm{mg}$ of comb. The results are shown in Table 4. TABIE 4 - Radioactivity of THE VARIOUS LIPID FRACTIONS ISOLATED AFTER FEeding;
UNIFORMLY LABELLED GLUCOSE- ${ }^{14} \mathrm{C}$, EXPRESSED AS COUNTS/MIN

\begin{tabular}{lc} 
& Counts/min \\
Food & 494 \\
$\mathrm{CO}_{2}$ excreted (after 1 day) & 167 \\
$\mathrm{CO}_{2}$ excreted (after 2 days) & 366 \\
$\mathrm{CO}_{2}$ excreted (after 4 days) & 418 \\
$\mathrm{CO}_{2}$ excreted (after 6 days) & 446 \\
Petroleum ether extract of the head & 56 \\
Petroleum ether extract of the thorax & 9 \\
Petroleum ether extract of the legs & 24 \\
Petroleum ether extract of the abdomen & 297 \\
Petroleum ether extract of the ventriculus & 207 \\
Petroleum ether extract of the rectum & 30 \\
Petroleum ether extract of the eviscerated bees & 556 \\
Fraction hydrocarbons & 421 \\
Fraction alcohols & 480 \\
Fraction fatty acids & 519 \\
Petroleum ether extract of the comb & 580 \\
Fraction hydrocarbons & 544 \\
Fraction alcohols & 581 \\
Fraction fatty acids & 334 \\
Fraction wax acids & 307 \\
\hline
\end{tabular}

It is clear that, after feeding uniformly labelled glucose, the different lipid fractions are labelled in the same order of magnitude.

(5) Micro-autoradiographic assays

In accordance with the observations (see Introduction) that the fat cells and the oenocytes play a prominent part in the biosynthesis of beeswax, it was 


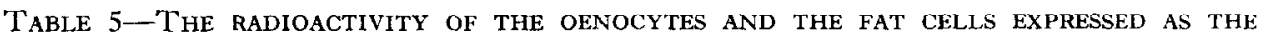
NUMBER OF GRAINS PER $9 \mu^{2}$ PRESENT IN THE EMULSION ABOVE THE CELLS, AFTER FEEDING ACETATE $-1-{ }^{14} \mathrm{C}$. BACKGROUND $=1.5$ GRAINS $/ 9 \mu^{2} . \mathrm{O} / \mathrm{F}=$ QUOTIENT OF THE AVERAGE ACTIVITY OF THE OENOCYTES AND THAT OF THE FAT CELLL. $n=$ NUMBER OF $9 \mu^{2}$ UNITS

\begin{tabular}{|c|c|c|c|c|c|}
\hline \multirow[t]{2}{*}{$\begin{array}{l}\text { Prep. } \\
\text { number }\end{array}$} & \multicolumn{2}{|c|}{$\begin{array}{l}\text { Grains } / 9 \mu^{2} \\
\text { above the } \\
\text { oenocytes }\end{array}$} & \multicolumn{2}{|c|}{$\begin{array}{c}\text { Grains } / 9 \mu^{2} \text { above } \\
\text { the fat cells at a } \\
\text { distance of } 2 \mu \\
\text { from the oenocytes }\end{array}$} & \multirow[t]{2}{*}{$\mathrm{O} / \mathrm{F}$} \\
\hline & & $n$ & & $n$ & \\
\hline 1 & $53 \cdot 3 \pm 4 \cdot 5$ & 7 & $34 \cdot 2 \pm 2 \cdot 2$ & 13 & $1 \cdot 56 \pm 0 \cdot 17$ \\
\hline 2 & $44 \cdot 1 \pm 2 \cdot 1$ & 8 & $27 \cdot 2 \pm 3 \cdot 0$ & 22 & $1.62 \pm 0.11$ \\
\hline 3 & $38 \cdot 7 \pm 1 \cdot 5$ & 12 & $32 \cdot 6 \pm 1 \cdot 8$ & 16 & $1 \cdot 17 \pm 0 \cdot 19$ \\
\hline 4 & $34.9 \pm 1.9$ & 15 & $25 \cdot 1 \pm 0 \cdot 7$ & 14 & $1 \cdot 39 \pm 0.10$ \\
\hline 5 & $36 \cdot 3 \pm 2 \cdot 5$ & 10 & $32 \cdot 4 \pm 1 \cdot 4$ & 20 & $1.21 \pm 0.12$ \\
\hline 6 & $48 \cdot 4 \pm 2 \cdot 3$ & 11 & $38 \cdot 2 \pm 2 \cdot 7$ & 6 & $1.27 \pm 0.14$ \\
\hline$i$ & $46 \cdot 0 \pm 2 \cdot 2$ & 10 & $40 \cdot 5 \pm 1 \cdot 5$ & 10 & $1.14 \pm 0.09$ \\
\hline$\varepsilon$ & $48 \cdot 0 \pm 2 \cdot 0$ & 8 & $33 \cdot 4 \pm 1 \cdot 6$ & 7 & $1.44 \pm 0.09$ \\
\hline Ave::age & $43 \cdot 7 \pm 1 \cdot 5$ & 81 & $33 \cdot 0 \pm 0 \cdot 8$ & 108 & $1 \cdot 32 \pm 0 \cdot 06$ \\
\hline
\end{tabular}

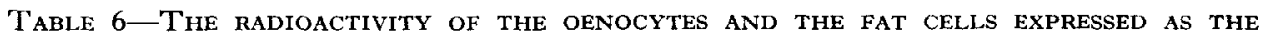
NUMBER OF GRAINS PER $9 \mu^{2}$ PRESENT IN THE EMULSION ABOVE THE CELLS, AFTER FEEDING GLUCOSE- ${ }^{14} \mathrm{C}$. FiaCKGROUND $=1.5$ GRAINS $/ 9 \mu^{2} . \mathrm{O} / \mathrm{F}=$ QUOTIENT OF THE AVERAGE ACTIVITY OF THE OENOCYTES AND THAT OF THE FAT CELLS. $n=$ NUMBER OF $9 \mu^{2}$ UNITS

\begin{tabular}{|c|c|c|c|c|c|}
\hline \multirow[t]{2}{*}{$\begin{array}{l}\text { Prep. } \\
\text { nurnber }\end{array}$} & \multicolumn{2}{|c|}{$\begin{array}{l}\text { Grains } / 9 \mu^{2} \\
\text { above the } \\
\text { oenocytes }\end{array}$} & \multicolumn{2}{|c|}{$\begin{array}{l}\text { Grains } / 9 \mu^{2} \text { above } \\
\text { the fat cells at a } \\
\text { distance of } 2 \mu \\
\text { from the oenocytes }\end{array}$} & \multirow[t]{2}{*}{$\mathrm{O} / \mathrm{F}$} \\
\hline & & $n$ & & $n$ & \\
\hline 1 & $8 \cdot 3 \pm 0.9$ & 15 & $12 \cdot 1 \pm 0 \cdot 9$ & 18 & $0.69 \pm 0.17$ \\
\hline 2 & $7 \cdot 7 \pm 0 \cdot 6$ & 13 & $8 \cdot 3 \pm 0 \cdot 7$ & 15 & $0.93 \pm 0 \cdot 16$ \\
\hline 3 & $8 \cdot 3 \pm 0 \cdot 6$ & 13 & $9 \cdot 9 \pm 0 \cdot 8$ & 13 & $0.84 \pm 0.15$ \\
\hline 4 & $8.7 \pm 0.6$ & 12 & $9 \cdot 5 \pm 0.7$ & 13 & $0.92 \pm 0.14$ \\
\hline 5 & $10 \cdot 7 \pm 1 \cdot 1$ & 9 & $11 \cdot 0 \pm 0.5$ & 12 & $0.97 \pm 0.15$ \\
\hline 6 & $10 \cdot 3 \pm 0 \cdot 7$ & 9 & $13 \cdot 1 \pm 0.7$ & 17 & $0.79 \pm 0.12$ \\
\hline 7 & $11.4 \pm 0.5$ & 16 & $12 \cdot 1 \pm 0 \cdot 4$ & 15 & $0.94 \pm 0.08$ \\
\hline 8 & $10 \cdot 1 \pm 0 \cdot 6$ & 16 & $12 \cdot 4 \pm 0.5$ & 15 & $0 \cdot 82 \pm 0 \cdot 10$ \\
\hline Average & $9 \cdot 4 \pm 0 \cdot 1$ & 103 & $10 \cdot 1 \pm 0 \cdot 1$ & 118 & $0.93 \pm 0.02$ \\
\hline
\end{tabular}

interesting to examine the activities of these two tissues after feeding radioactive acetate or glucose.

The animals were fed with a sugar paste containing either $10 \mu \mathrm{c}$ sodium aceta.e- $1-{ }^{14} \mathrm{C}$ or $10 \mu \mathrm{c}$ uniformly labelled glucose- ${ }^{14} \mathrm{C}$ per $\mathrm{g}$. 
In order to exclude chemographic phenomena (i.e. chemical actions of the different cells on the strip) we also examined unlabelled preparations. No differences could be ascertained between the density of the grains over the different cell types and the parts of the preparations where only strip and glass were present.

The results of these experiments are shown in Tables 5 and 6.

\section{DISCUSSION}

As oenocytes and fat cells occur only in insects, Hollande (1914) supposed that both kinds of cells are involved in the production of the initial compounds necessary for the production of wax. According to WIGGLesworth $(1947,1948)$

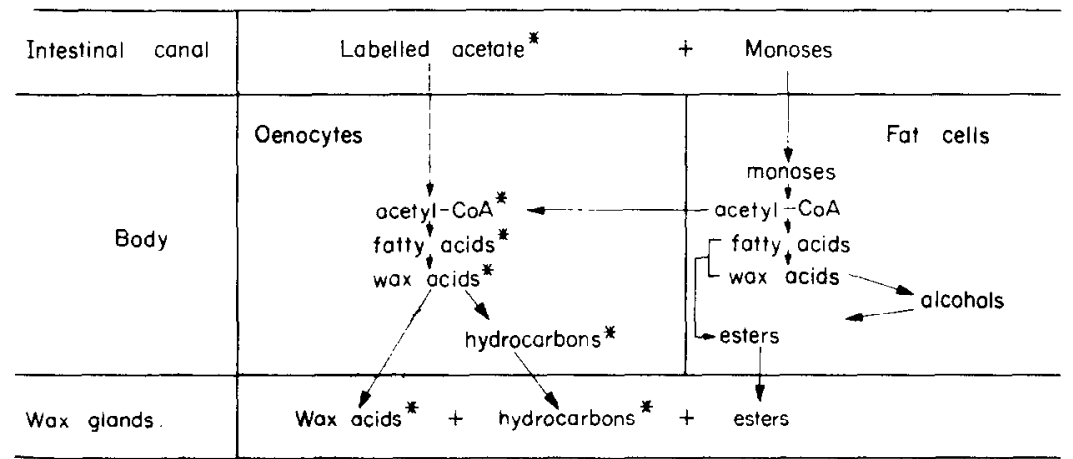

FIG. 1. Hypothetical representation of the synthesis of the components of beeswax.

and Kramer and Wigglesworth (1950) the oenocytes of Rhodnius, Tenebrio, and Periplaneta are additionally responsible for the production of the cuticle lipids. As in honeybees a transport of substances from fat cells and oenocytes to the wax glands has been demonstrated (Rösch, 1930) and later on a transmission of products from fat cells to oenocytes has been observed (ReimanN, 1952), there seems to be a close relationship between these two kinds of cells and the wax glands.

After feeding sucrose containing deuterio- or ${ }^{14} \mathrm{C}$-labelled acetate the hydrocarbons and the free wax acids were strongly labelled, whereas the esters as well as the acids and alcohols that compose them wcrc wcakly labelled. This result, combined with the histological data mentioned above, points to synthesis of the esters on the one hand and the free wax acids and hydrocarbons on the other hand in different kinds of tissues.

We formed the hypothesis that the tissue responsible for the synthesis of the esters is unable to take up acetic acid or active acetate, but is able to take up monoses from the body fluid. It is in accordance with this hypothesis that in the experiments in feeding heavy water or uniformly labelled glucose- ${ }^{14} \mathrm{C}$ no pronounced differences have been observed in the labelling of the various fractions.

The tissue responsible for the synthesis of the highly labelled wax acids and hydrocarbons must be able to take up acetate (or some related compound) derived 
from the degradation of sugars in the other tissue. This could account for the observations of REIMANN (1952). Both tissues, oenocytes and fat cells, transmit their lipid products into the wax glands. In connexion with the investigations of Rösch and REImanN it is obvious that the ester-making tissue consists of fat cells and that the oenocytes make the wax acids and the hydrocarbons. The hypothesis is represented in Fig. 1.

It is in accordance with this hypothesis that after feeding labelled acetate the oenocytes have a higher radioactivity than the fat cells. The differences between the activity in the case of the micro-autoradiographic assays are small compared with those of the biochemical assays. The fat body, however, also plays a prominent part in the amino acid metabolism in insects (Sirigematsu, 1958). It has been shown (URICH, 1961) that the fat body is not only an important storage organ but also an organ in which numerous specific anabolic processes occur.

The activity of many enzymes related to the catabolic processes is relatively low in the fat body of insects (URICH, 1961). Probably the fat body plays an important part in anabolic processes. In Bombyx the protein synthesis stands out (Shigematsu, 1958); in Apis mellifera it is the lipid synthesis that is very striking.

Acknowledgements-I am indebted to Professor Dr. H. J. Vonk for his interest and the reading of the manuscript and to Dr. Ph.D. J. W. SEDEe for technical instructions. I am also indebted to Professor Dr. J. DE WILDE for his encouragement and advice, to the agricultural organization T.N.O., and to the association Euratom-Ital and to Ir. G. SAUER for their help with the micro-autoradiography.

\section{REFERENCES}

Beament J. W. L. (1955) Wax secretion in the cockroach. F. exp. Biol. 32, 514-538.

Bence W. P. J. (1960) Staining autoradiographs at low temperature. Stain Tech. 35, 106-108.

Calvin M., Heidelberger C., Reid J. C., Tolbert B. M., and Yankwich P. E. (1949) Isotopic Carion. J. Wiley, New York.

Dennel R. and Malik S. K. A. (1956) 'The cuticle of the cockroach Periplaneta americana V. Proc. roy'. Soc. (B) 144, 545-556.

Dreyling I. (1905) Die wachsbereitende Organe bei den gesellig lebenden Bienen. Zool. fb. (Anat.) 22, 289-330 (Vol. 1906).

Fuchs W. and DE Jong A. (1954) Chromatographische Zerlegung von Bienenwachs. Fette u. Seif. 56, 218-220.

GI.YNNE-JoNes G. D. (1955) The cuticular waterproofing mechanism of the worker honeybee. F. exp. Biol. 32, 95-109.

Gray P. (1954) The Microtomist Formulary and Guide. Blakiston, New York.

DE Grout A. P. (1953a) Protein and amino acid requirements of the honeybee (Apis mellifica). P'hysiol. Comp. 3, 197-285.

de Groot A. P. (1953b) Protein and amino acid requirements of the honeybee (Apis mellifica). Thesis, University of Utrecht, Netherlands.

Holdgate M. W. and Seal M. (1956) The epicuticular wax layers of the pupa of Tenebrio molitor L. F. exp. Biol. 33, 82-106.

Hollande A. C. (1914) Les cérodécytes ou "oenocytes" des insectes considérés au point de vue biochimique. Arch. Anat. Micr. 16, 1-66.

Huber F. (1814) Nouvelles Observations sur les Abeilles, II. Paschoud, Genève.

JoHN M. (1684) Ein Bienenbiuchel. Lauban. 
Keston A., Rittenberg D., and Schoenheimer R. (1937) Determination of deuterium in organic compounds. F, biol. Chem. 122, 227-237.

Kramer S. and Wigglesworth V. B. (1950) The outer layers of the cuticle in the cockroach Periplaneta americana, and the function of the oenocytes. Quart. $\%$. micr. Sci. 91, 63-72.

LOCKE M. (1960) The cuticle and wax secretion in Calpodes ethlius (Lepidoptera, Hesperidae). Quart. F. micr. Sci. 101, 333338.

Prek T. (1961) Synthesis of wax in the honeybee (Apis mellifera L.). Proc. Acad. Sci. Amst. 64, 648-654.

PIEk T. (1962) Over de vorming van was bij de honingbij (Apis mellifera) L. Thesis, University of Utrecht, Netherlands.

REIMANN K. (1952) Neue Untersuchungen über die Wachsdrüse der Honigbiene. Zool. Fb. (Anat.) 72, 251-271.

Rösch G. A. (1930) Untersuchungen über die Arbeitsteilung im Bienenstaat. $Z$. rergl. Physiol. 12, 1-71.

Seidel C. F., Müller P. H., and Schninz H. (1944) Über die Alkohole, Kohlenwasserstoffe und Oxyde der Sesquiterpenreihe aus französischem Lavendelöl. Helv. Chim. Acta 27, 738-747.

Shigematsu H. (1958) Synthesis of a blood protein by the fat body in the silkworm Bombyx mori L. Nature, Lond. 182, 880-882.

SPengler G. and Wöllner E. (1954) Adsorptive Trennung von Wachsen und Wachskomponenten. Fette u. Seif. 56, 775-784.

URICH K. (1961) Mitteldarmdrüsen und Insektenfettkörper als Zentralorgane des Stoffwechsels. Ergebn. Biol. 24, 155-190.

Warth A. H. (1947) The Chemistry and Technology of Waxes. Reinhold, New York.

Wigglesworth V. B. (1947) The epicuticle in an insect, Rhodnius prolixus (Hemiptera). Proc. roy. Soc. (B) 134, 163-181.

Wigglesworth V. B. (1948a) The insect as a medium of the study of physiology. Proc. roy. Soc. (B) 135, 430-446.

Wigglesworth V. B. (1948b) The insect cuticle. Biol. Rev. 23, 408-451.

WigglesworTH V. B. (1948c) The structure and deposition of the cuticle in the adult mealworm Tenebrio molitor (Coleoptera). Quart. F. micr. Sci. 89, 197-218. 